\title{
Chromosomal Localization of 15 Ion Channel Genes
}

\author{
Mark W.W. Russell, ${ }^{12}$ Stan du Manoir, ${ }^{3}$ David .J. Munroe, ${ }^{4}$ \\ Francis S. Collins, ${ }^{2}$ and Lawrence C. Brody ${ }^{2}$ \\ Deparmems of Pediatres and Communicable Diseases, Human Genetres, and Internal Medicme, \\ University of Michigan, Ann Arbor, Michigan; ${ }^{2}$ Laboratory of Gene Transfer, ${ }^{3}$ Diagnostic Development Branch. \\ The National Center for Human Genome Researdh. National Instututes of Healnh, Bethesda. Maryland; \\ +Center for Cancer Reseach. Massachusetts Institute of Technology, Cambridge. Massachusetts.
}

Recelved 23 September 1996-Final 23 September 1996

\begin{abstract}
Several human Mendelian diseases, including the long-QT syndrome, malignant hyperthermia, and episodic ataxialmyokymia syndrome, have recently been demonstrated to be due to mutations in ion channel genes. Systematic mapping of ion channel genes may therefore reveal candidates for other heritable disorders. In this study, the GenBank and dbEST databases were used to identify members of several ion channel families (voltage-gated calcium and sodium, cardiac chloride, and all classes of potassium channels). Genes and ESTS without prior map localization were identified based on GDB and $O W L$ database information and 15 genes and ESTs were selected for mapping. Of these 15, only the serotonin receptor 5HT3R had been previously mapped to a chromosome. A somatic cell hybrid panel (SCH) was screened with an STS from each gene and, if necessary, the results verified by a second SCH panel. For three ESTS, rodent derived PCR products of the same size as the haman STS precluded SCH mapping. For these three, human PI clones were isolated and the genomic location was detemined by metaphase FISH. These genes and ESTS can now be further evaluated as candidate genes for inherited cardiac, neuromuscular, and psychiatric disorders mapped to these chromosomes. Furthermore, the ESTs developed in this study can be used to isolate genomic clones, enabling the determination of each transcript's genomic structure and physical map location. This approach may also be applicable to other gene families and may aid in the identification of candidate genes for groups of related heritable disorders.
\end{abstract}

\section{INTRODUCTION}

Ion channels are integral components of intra- and intercellular signaling, electrolyte homeostasis, and osmotic regulation. Recently, several heritable human diseases, including the long-QT syndrome (1-3), malignant hyperthermia (4), and episodic ataxia/myokymia syndrome (5) have been determined to be a consequence of ion channel defects. In each case, the disease gene was initially determined to be a candidate based upon its physical proximity to the disease locus as mapped by linkage analysis [the "positional candidate" approach, (6)]. A vast number of human ion channels have been identified using a variety of different strategies: functional cloning, random sequencing of cDNAs, and identification of the human homologues and relatives of known Drosophila (7), rodent (8), and human genes (9). Due to their potential role in human diseases, a systematic mapping of these ion channels and their related expressed sequence tags (ESTs) may be beneficial to positional cloning projects involving inherited cardiovascular, neuromuscular, or psychiatric disorders. 
In this study we sought to localize members of several ion channel families using the following algorithm. Previously unmapped members of several ion channel families-voltagegated sodium and calcium channels, cardiac chloride channels, and several potassium channel families - were identified. Sequence from a representative member of each family [voltagegated sodium (embl:M91556); voltage-gated calcium (L06110, embl:M59786); chloride (P35526); potassium (embl:M26685, JU0271, P25122, embl:M55515, embl:M61157, embl: $\mathrm{X} 16476, \mathrm{~A} 38074, \mathrm{U} 12507$ ) channels] was used to search the non-redundant GenBank database [BLAST programs, (10)]. All members of each gene family represented in the public databases were identified, including previously-cloned genes and ESTs. GenBank accession numbers for each gene or EST were used to retrieve mapping information from the GDB (11) and OWL (12) databases. All highly homologous genes and ESTs which had not been mapped as of June 1, 1995 were identified for further evaluation. Each of the 20 previously-unmapped entries was then used to search the nonredundant GenBank database. Five of the ESTs were removed from further consideration due to nearly identical nucleotide sequence matches (except for single base pair insertions or deletions in the coding sequence) with other genes or ESTs. These five ESTs were assumed to be identical to the previously-mapped genes that they matched.

\section{METHODS}

Chromosomal Localization. The somatic cell hybrid panel DNA was purchased from Coriell Institute (Camden, New Jersey, NIGMS monochromosomal panel) or Bios Laboratories Inc. (New Haven, Connecticut, polychromosomal panel). P1 DNA was prepared using the Qiagen Maxi prep kit (Qiagen Inc., Chatsworth, California). Human genomic P1 genomic library clones (DMPC-HFF \#1; 13) were isolated by PCR screening. The chromosomal location of these Pls were determined by FISH using standard methods (14). DAPI was used as a DNA counterstain. Images were acquired using IPlab Spectrum (Signal Analytics Corporation, Virginia).

Database Searching, and STS Generation. Sequences for ion channel related genes were extracted from GenBank by serial BLAST searches (using the default parameters) through June 1995. STS primer sequences are shown in Table 1. PCR reactions were performed under standard conditions in a Perkin-Elmer (Branchburg, New Jersey) 9600 thermal cycler. After 4 minutes of denaturation at $94^{\circ} \mathrm{C}$, thirty-five cycles were performed as follows: 1 minute at $94^{\circ} \mathrm{C}, 45$ seconds at annealing temperature, 2 minutes at $72^{\circ} \mathrm{C}$. The products were resolved on a $3 \%$ agarose $2 \%$ Nusieve agarose (FMC Products, Rockland, Maine).

\section{RESULTS}

Primers to amplify sequence tagged sites (STSs) were designed from the $3^{*}$ end of the available sequence for each of the remaining 15 genes and used to screen a monochromosomal somatic cell hybrid (SCH) panel (Fig. 1). For those genes that could not be unambiguously mapped using this panel, a second, polychromosomal SCH panel (Bios Laboratories Inc., New Haven, Connecticut) was screened to verify the results. Nine genes were mapped using only the monochromosomal panel (SCH), and three mapped using both panels [SCH $(\times 2)]$ (Table 1). Three genes could not be mapped using $\mathrm{SCH}$ panels due to the presence of an identicallysized PCR product from mouse or hamster DNA. For these three genes, a human genomic $\mathrm{Pl}$ clone was isolated by PCR screening. The chromosomal location of these $\mathrm{P} 1$ s were determined by FISH. Each P1 gave an unambiguous signal (Fig. 2).

Since, prior to this study, two loci for the inherited cardiac repolarization defect, long-QT syndrone, had been determined to be secondary to ion channel defects $(1,2)$ and given our interest in the long QT syndrome Iocus that maps to $11 \mathrm{p} 15.5$ (LQT1) $(15,16)$, the two ion 


\begin{tabular}{|c|c|c|c|c|c|c|}
\hline $\begin{array}{l}\text { Gene } \\
\text { lamily }\end{array}$ & $\begin{array}{c}\text { Accession } \\
\text { number }\end{array}$ & $\begin{array}{l}\text { Prmer } \\
\text { sequence }\end{array}$ & $\begin{array}{l}\text { Annealing } \\
\text { Temperantre }\end{array}$ & $\begin{array}{l}\text { Anplified } \\
\text { product } \\
\text { size }\end{array}$ & $\begin{array}{l}\text { Mapping } \\
\text { method }\end{array}$ & $\begin{array}{l}\text { Chromosomal } \\
\text { location }\end{array}$ \\
\hline \multicolumn{7}{|l|}{ Potassium channels } \\
\hline hSlo (Ca-dep K') & 013913 & $\begin{array}{l}\text { 5'-TTHCCCTGTTICCCCTGTAGTCC } \\
\text { 5'-GGTCCGTCTGCTTATTTGCTGTRG }\end{array}$ & 53 & 136 & $\mathrm{SCH}$ & 10 \\
\hline $\mathrm{K}$ channel & 102840 & $\begin{array}{l}\text { 5'-CAGCGCAAAACCCTTACTCAAATG } \\
\text { 5'-TCCTCCTCCAACCCTAAACAATG }\end{array}$ & 60 & 201 & $\mathrm{SCH}$ & 20 \\
\hline C-ATP ( $\mathrm{K}+$ channel) & $X 83582$ & $\begin{array}{l}\text { 5'GGGGCCACCGATTCACACCAGT } \\
\text { 5'AGCCGGCTTCCTCTTCATTTCT }\end{array}$ & 64 & 142 & FISH & $11 q 25$ \\
\hline HHIRK & 112507 & $\begin{array}{l}\text { 5'-CGAAGTCCCCAACACTCCCCTT } \\
\text { 5'-GGCGTGTCCGTACTAGTGCTTTCT }\end{array}$ & 62 & 165 & $\mathrm{SCH}$ & 17 \\
\hline $\begin{array}{l}\text { HERG-like } \mathrm{K} \\
\text { channel }\end{array}$ & $F 02206$ & $\begin{array}{l}\text { 5'GTGATTCCGGCTTTTATTCCATT } \\
\text { 5'TGCTGCGAGTAAAAGAGTCATTC }\end{array}$ & 54 & 194 & $\mathrm{SCH}$ & 2 \\
\hline ROM-K ${ }^{+}$ & $\mathrm{U} 12542$ & $\begin{array}{l}\text { 5-GTAACAGTGGCTTTTCAACAGGAGTA } \\
\text { 5'-GCGGGGCTCAGGGGTCTT }\end{array}$ & 56 & 146 & $\mathrm{SCH}(+11)$ & $11 q 21-25$ \\
\hline $\mathrm{KCHC}(\mathrm{K}$ channel) & $\mathrm{L} 02752$ & $\begin{array}{l}\text { 5'-ACCATTGGGGGAAAGATAGTG } \\
\text { 5'-CTCCCGGTGGTAGAAGTAGTTG }\end{array}$ & 53 & 111 & $\mathrm{SCH}$ & 1 \\
\hline camblac beta subunit & L.39833 & $\begin{array}{l}\text { 5'-TGTCTGCTGTCGCTACCACTGT } \\
\text { 5-GCCCCCATATTCTTCCCATTG }\end{array}$ & 53 & 142 & SCH & 3 \\
\hline \multicolumn{7}{|l|}{ Chloride channels } \\
\hline $\mathrm{CL}$ channel & $\mathrm{T} 17495$ & $\begin{array}{l}\text { 5-CTTCCTGGTCCCCGACGCAA } \\
5^{\prime} \text {-GCCCCATCACTGCCAGCCTTC }\end{array}$ & 64 & 77 & $\mathrm{SCH}(\times 2)$ & 17 \\
\hline $\begin{array}{c}\mathrm{CL}-\text { channel (P64 } \\
\text { homologue) }\end{array}$ & T11650 & $\begin{array}{l}\text { 5'AGCTCGTCGCCATCCAAAAACT } \\
\text { 5'-CCOCCCTCCCAGAAGAAGTG }\end{array}$ & 60 & 82 & $\mathrm{SCH}\left(\mathrm{X}_{2}\right)$ & 6 \\
\hline CL- channel & $\mathrm{T} 92523$ & $\begin{array}{l}5^{5} \text {-CCCTCTGCCTGATGAAATAGATGC } \\
5^{\prime} \text {-CTCGTCCCACCCAGAAACTT }\end{array}$ & 58 & 79 & FISF & 21422.1 \\
\hline CL" channel & 724611 & $\begin{array}{l}\text { 5.CATCCCCCCTCCCAGAAGAAGTG } \\
\text { 5.GGGTGAGCTCGTTGCCATCCA }\end{array}$ & 64 & 89 & FISH & $6 \mathrm{n} 21.3$ \\
\hline $\begin{array}{l}\text { CL" channel regula- } \\
\text { tory protenn }\end{array}$ & F00895 & $\begin{array}{l}\text { 5'-GAAGATGGGATGGAGGTGGATA } \\
\text { 5'-CTGGTTCAGGTTGGGTTTTGG }\end{array}$ & 58 & 193 & SCH & 6 \\
\hline $\begin{array}{l}\text { Ligand-gated channel } \\
\text { 5HT3R (serotonn } \\
\text { receptor) }\end{array}$ & D49394 & $\begin{array}{l}\text { 5'-ACTGCAGCCACATGGGAGGACC } \\
\text { 5-CATTGGAAACAGGGCACGGGACTT }\end{array}$ & 62 & 427 & $\mathrm{SCH}(+\mathrm{J1})$ & $11 q 21-25$ \\
\hline $\begin{array}{l}\text { Putative chamel } \\
\text { MYASTHAgB }\end{array}$ & & & & & & \\
\hline MYASTH AgB & $\$ 60415$ & $\begin{array}{l}\text { 5.GCACCGAGTGACTGAATGGTTGAGA } \\
\text { 5'ATACAGAGCGAGGTGGGCAGAATG }\end{array}$ & 58 & 98 & $\mathrm{SCH}\left(X_{2}\right)$ & 10 \\
\hline
\end{tabular}

channel genes that mapped to chromosome 11 were further localized using somatic cell hybrids that were derived from the J1 series (17) and contain subfragments of human chromosome 11. One of these genes, $5 H T 3 R$, a serotonin receptor that functions as a ligandgated cation channel, had previously been mapped to chromosome 11 (18) but had not been further localized. Both $5 H T 3 R$ and the ROM-K potassium channel were localized to 11 q21-25 using this panel. During the course of this work the gene responsible for chromo some 11-linked long QT syndrome (LQT1) was identified by positional cloning (3). This novel potassium gene, KVLQTI, was not represented in the dbEST database.

Two genes in this study map to chromosomes known to contain a related transcript. Recently, hSlo, a novel relative of the slowpoke calcium-dependent potassium channel, was cloned and characterized (19). In this study, we mapped hSlo to chromosome 10.
The slowpoke gene had previously been mapped to chromosome $10(20)$, and shares nucleotide identity with $h$ Slo over $70 \%$ of the coding sequence. However, the $5^{\prime}$ coding sequence and the $3^{\prime}$ untranslated sequence (from which the STSs were generated) are markedly different between the two genes. Therefore, they could represent two different loci on chromosome 10, however, we can not rule out that they do not share multiple exons in common. This mapping information, combined with the extensive differences in the translated portion of the mouse mSlo gene (21), suggest that $h$ Slo and slowpoke could also be altematively-spliced forms of the same gene.

Secondly, two ESTs with homology to the same sequence of the bovine P64 chloride channel mapped to chromosome 6 , and shared a nucleotide sequence identity of approximately $90 \%$. However, the nucleotide mismatches in the putative coding sequence were randomly 
Russell et al.

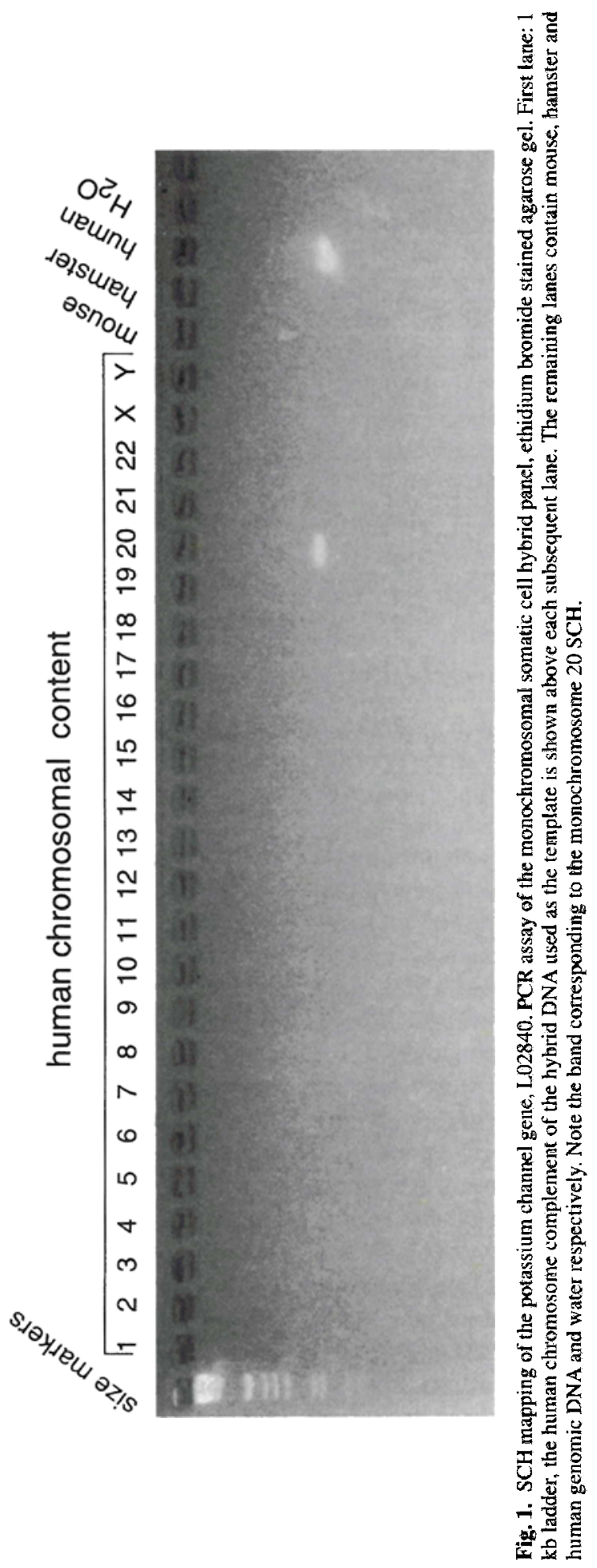



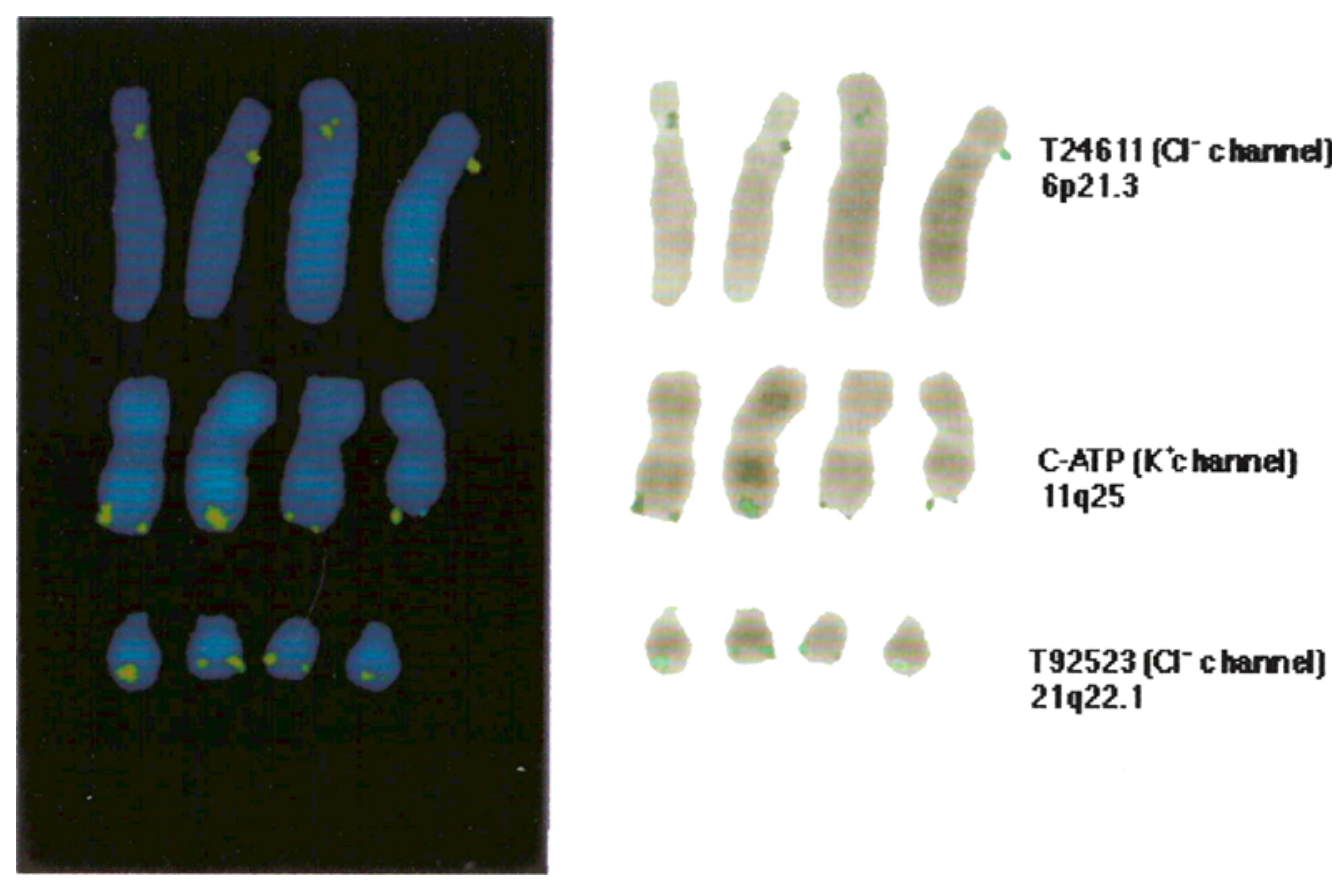

Fig. 2. FISH of the C-ATP potassium channel. and two putative chloride channels. Results from metaphase chromosome spreads from a human lymphocyte cell line. Lefi panel. DAPI stained chromosomes, probe signal is shown in green (FITC). Right panel, hybridization signals are superimposed on video inverted DAPI image to facilitate band identification. Top. FISH analysis using a PI (70F9) probe for a chloride chamel homologue gene (T24611) demonstrates a single hybridization signal on the short arm of chromosome 6 . Middle, hybridization with PI (57F7) containing the C-ATP ( $\mathrm{K}^{+}$channel) gene at the end of the long arm of chromosome 11. Bottom. P1 (6A11) probe containing a putative chloride channel (T92523) localized to chromosome $21 \mathrm{q} 22.1$.

distributed rather than primarily third base pair changes and often were single base pair insertions or deletions. Therefore, these two ESTs may represent 1) a single gene with sequencing errors of the ESTs, 2) a gene and an expressed processed pseudogene, or 3) two different genes.

Since the completion of this study, the chromosomal localization of four of these genes has been independently confirmed by either the Cooperative Human Linkage Center (CHLC) (U13913, S60415), the Whitehead Institute (L02840) or the Stanford (U12542) EST mapping projects. For the potassium channel L02840, our somatic cell hybrid mapping result strengthens its localization on a chromosome 20 YAC contig (GenBank) which was based on STS content mapping of two chimeric YACs.

\section{DISCUSSION}

With the rapid development of a "transcript map" of the human genome, the chromosomal and eventually subchromosomal localization of nearly all publicly available ESTs may be performed by the transcript mapping projects at the Whitehead Institute, Stanford and other centers. In the near future, it may be possible to perform candidate cloning of human disease genes using a fully-developed transcript map to identify all the candidate genes in the region of interest as defined by linkage analysis. However, directed efforts to map gene families, as was performed in this study, may currently still be beneficial in mapping and identifying candidate genes for certain types of human diseases.

In conjunction with linkage studies, the data presented here will now allow these 15 
genes to be considered as candidates for human diseases that have been mapped to specific chromosomes. For example, one of the human diseases that is likely secondary to an ion channel dysfunction, rippling muscle disease (RMD ), maps to chromosome 1q41 (22). This disorder is characterized by muscle cramps, pain and stiffness, particularly following exercise and is secondary to electrically silent muscle contractions that are elicited by mechanical stimuli. One of the genes in this study, $K C H C$, is an inward rectifying potassium channel that is expressed in nervous tissue and maps to chromosome 1. $K C H C$ has three potential calcium-calmodulin-dependant (CaM II) protein kinase phosphorylation sites (7) which might make it responsive to mechanical stimuli.

Two of the other mapped genes the HH-LRK potassium channel and a putative chloride channel) map to chromosome 17 , which contains a locus for malignant hyperthermia ( $M H S 2 ; 23$ ). Other diseases which may be secondary to ion channel defects and map to one of these chromosomes include juvenile myoclonic epilepsy I $(6 p ; 24)$ and an EEG variant disorder (EEGVl; 25) on chromosome 20. These mapped genes can now be evaluated as candidates for other neurologic, cardiovascular, neuromuscular, or psychiatric disorders. Furthermore, they may be considered as candidates for as yet unmapped disorders or for disorders with genetic heterogeneity where not all of the loci have been identified, such as the long-QT syndrome and RMD. The STSs described in this paper can be used to place these genes on the physical maps for that chromosome and aid in their evaluation as candidates for human diseases.

\section{NOTE ADDED IN PROOF}

The following genes have now been mapped by radiation hybrid analysis: F02206, V12542, L39833, D49394 and S60415. Please see Science 274:540-546.

\section{ACKNOWLEDGMENTS}

We would like to thank Christiano Cummings for help with the isolation of P1 clones. This work was supported by a National Research Service Award (M.W.W.R.).

\section{LITERATURE CITED}

1. Wang, Q., Shen, J., Splawski, 1., Atkinson, D., Li, Z., Robinson, J., Moss, A.J.. Towbun, J.A., and Keating, M.T. 1995. SCN5A matations associated with an inherited cardiac arrhythmia, Long QT Syndrome. Cell 80:805-811.

2. Curran. M.E.. Splawskı, I, Timothy, K, Vincent, G.M., Green, E.D.. alnd Keating, M.T. 1995. A molecular basis for cardiac arrhythmia: HERG mutations cause Long QT Syndrome. Cell 80:795-803.

3. Wang Q., Curran, M.E. Splawski, I, Burn, T.C. Millholland, J.M., VanRaay, T.J., Shen. J., Timothy, K.W. Vincent G.M., de Jager. T., Schwartz. PJ.. Towbin. J.A., Moss, A.J.. Alkmson. D.L., Landes, G.M., Comnors, T.D. and Keating, M.T. 1996. Positional cloning of a novel potassium channel gene: KVL.QT7 mutatyons cause cordiac arthy thmias. Nature Genettes 12:17-23.

4. Quane, K.A. Healy. IM.S.. Keatno, K.E. Mannmg, B.M. Couch, F.J. Paimuce. I.M., Dorimzas, C. Featerlund, T.H. Bera, K.. Ordiong, H., Bendixen, D. Morimer. W., Lmz. U.. Muller. C.R., and McCarthy, T.V. 1993. Mutatuons in the lyarodine receptor gene in central core disease and malignant hyperthorma. Nature Genet 5:51-55

5. Browne, D.L., Gancher, S.T.. Nutt, J.G., Brunt. E.R.P.. Smith, E.A., Kramer, P., and Litt, M. 1994. Eprsodic ataxı/myokyma syndone is associated with point mutations in the human potassium channel gene. KCNAI. Nature Genet. 8:136-140

6. Collins, F.S. 1995. Positional clonmg moves from perditional to traditional. Nature Genet. 9:347-350.

7. Ramaswami, M. Gautam, M. Kamb. A. Rudy, B.. Tanouye. M.A., and Mathew, M.K. 1990. Human potassium chanoel genes: molecular clonng and functional expression. Mol, Cell. Neuroset 1:214223.

8. Ried. T., Rudy, B. Vega-Saenz de Miera, E., Lau. D., Ward. D.C. and Sen, K. 1993. Localization of a hehly conserved human potassum chanel gene (NGK2KV4: KCNCl) 10 chromosome $11 \mathrm{p} 15$. Genomes 15:405-411.

9. Curran. ME. Landes, G., and Keating, M.T. 1992 Molecular clonmg, characterization and genomic localization of a homan polassum channel gene. Genomics 12:729-737.

10. Alschul, S.F. Gish, W., Miller. W., Myers, E.W., and Lipman. D.J. 1990. Basic local alignment search tool. I. Mol. Biol. 215:40,3-410.

11. Fasmen, K.H., Cuticcha, A.J., and Kingsbury, D.T. 1994. The GDB (TM) Human Genome Database Annotation. Nucl. Acuds Res. 22:3462-3469. 
12. Bleasby, A.J., and Wootton, J.C. 1990. Construction of validated, non-redundant composile protern sequence databases. Protein Eng. 3:153-159.

13. Shepard. N.S., Pfrogner, B.D.. Coulby, J.N., Ackerman, S.L., Vadyanathan, G. Sauer, R.H., Balkenhol, T.C., and Stemberg, N. 1994. Preparation and screening of an arrayed buman genomic library generated with the Pl cloning system. Proc. Natl. Acad. Sci, U.S.A. 91:2629-2633.

14. Pinkel, D., Straume, T., Gray, J.W. 1986. Cytogenettc analysis using quantitatuve, high-sensitivity, fluorescence hybridization. Proc. Natl. Acad. Sci. U.S.A. 83:2934-2938.

15. Keating. M., Atkinson. D., Dunn. C.. Tumothy, K., Vincent, G.M., and Leppert, M. 1991. Linkage of a cardiac arrhythmia, the long QT syndrome, and the Harvey ras-1 gene. Sctence 252:704-706.

16. Russell, M.W., Dick. M. II. Campbell, R.M., Hulse, J.E. Munroe, D.J., Bric, E. Hotsman, D.E., Collins, F.S., and Brody, L.C. 1995. Localization of RomanoWard long QT syndrome gene, LQT1. to the interval between tyrosine hydroxylase (TH) and D11S1349. Am. 1. Hum. Genet. 57:503-507.

17. Glaser. T. Housman, D., Lewts, W.H. Gerhard, D., and Jones, C. 1989. A fine-structure deletion map of human chromosome $11 \mathrm{p}$ : analysis of $\mathrm{J}$ l series hybnds. Somat. Cell Mol. Genet. 15:477-501.

18. Vetz. P., Abdelatty, F., Villatroel, A., Rappold, G., Weiss, B., and Koenen, M. 1994. Organtsation of the murine 5-HT3 receptor gene and assignment to human chromosome 11. FEBS Lettew 339:302-306.
19. Dworetzky, S.I., Trojnacki, J.T., and Gribkoff, V.K. 1994. Cloning and expression of a human largeconductance calcium-activated potassium channel. Brain Res. Mol. Brain Res. 27:189-1.93.

20. Pallanck, L., and Ganctzky, B. 1994. Clonung and characterization of human and mouse homologs of the Drosophila calcinm-activated potassium chanel gene. slowpoke. Hum. Mol. Genet. 3:1239-1243.

21. Butler, A., Tsunoda, S., McCobb, D.P., We. A., and Salkoff, L. 1993. mSlo, a complex mouse gene encoding "Maxi" calcium-activated potassium channels. Stitence 261:221-224.

22. Stephan, D.A., Buist, N.R., Chittenden, A.B., Ricker; K, Zhou, J., and Hoffman. E.P. 1994. A rippling muscle disease is localized to $1 \mathrm{q} 41$ : evidence for muluple genes. Neutology 44:1915-1920

23. Levitt, R.C., Nouri, N., Jedlicka, A.E., McKusıck, V.A. Marks, A.R., Shutack. J.G., Fletcher, J.E., Rosenbeyg, H. and Myers, D.A. 1992. Evidence for the localisation of a malignant hyperthermia Jocus (MHS2) to human chromosome 17\%. Genomics 14:562-566.

24. Wessbecker, K. Dumer, M., Scummelli, A., Janz, D.. Sparkes, R.S., Spence, M.A. 1991. Confimation of linkage between juvenile myoclonic epilepsy and the HLA region of chromosome 6. Am. $f$. Med. Genet. 38:32-36

25. Steinlein, O., Anokhin, A., Yping, M. Schalt, E., and Vogel, F. 1992. Localization of a gene for the human low-voltage EEG on $20 \mathrm{q}$ and genetic heterogenerty. Genonucs 12:69-73. 